\title{
The Objective Conditions of the Competency of Labor Social Security Practitioners in Facing Future Jobs
}

\author{
Naufal Mahfudz ${ }^{1 *}$, Arif Satria ${ }^{2}$, Aida Vitayala S. Hubeis ${ }^{3}$, Arif Imam Suroso ${ }^{4}$, Zaim Uchrowi $^{5}$ \\ 1,2,3, 4,5 Business School IPB University, Jl. Raya Pajajaran, 16151, Bogor, Indonesia
}

\begin{abstract}
Objective - The number of participants in the labor social security program in Indonesia managed by BPJamsostek, namely the Labor Social Security Administering Body, is still relatively low compared to the number of people working in Indonesia. Labor social security practitioners, or Account Representatives, are tasked with carrying out the process of acquiring new participants. The competence of practitioners needs to be further investigated to ensure their performance in increasing membership coverage.

Methodology/Technique - This study involved 335 practitioners in BPJamsostek branch offices in major cities throughout Indonesia. The sampling method used was purposive random sampling and the analytical tool used was descriptive statistical methods to map the perceptions and opinions of practitioners regarding their competence.

Findings \& Novelty - It is found that the practitioners are bachelor's degree graduates who have various educational backgrounds. This is very useful for making acquisitions of potential participants who also have diverse work professional backgrounds from both formal and informal sector workers. Career opportunities up to the highest level in the institution for practitioners are also wide enough to become Director, even as President Director. It was also found that the majority of respondents, $93.1 \%$, stated that they were ready to face future jobs in the context of participation in social security programs for employment. However, this readiness must be supported by the competencies that must be possessed by them, because $94.0 \%$ of the respondents stated that the competency development process was important and $52.5 \%$ stated that the opportunity to obtain competency development programs was not evenly distributed among practitioners.
\end{abstract}

Type of Paper: Empirical.

JEL Classification: E20, H55.

Keywords: Labour Social Security Practitioners; Competency; Jobs Lost; Future Jobs; Fourth Industrial Revolution Reference to this paper should be made as follows: Mahfudz, N; Satria, A; Hubeis, A.V.S; Suroso, A.I; Uchrowi, Z. (2021). The Objective Conditions of the Competency of Labor Social Security Practitioners in Facing Future Jobs, J. Bus. Econ. Review, 5(4) 18-25. https://doi.org/10.35609/jber.2021.5.4(2)

\section{Introduction}

According to Spicker (2000), the welfare state is a social welfare scheme that gives the state or government a greater role in allocating a portion of public funds to ensure that the basic needs of its people are met. Meanwhile, according to Husodo (2006), the welfare state is defined as a country in which the state government is considered responsible for ensuring the minimum standard of living welfare for every citizen. The existence and implementation of social security protection, including Labor social security, to all workers is very important in the context of realizing a welfare state.

\footnotetext{
*Paper Info: Revised: December 24, 2020

Accepted: March 31, 2021

* Corresponding author: Naufal Mahfudz

E-mail: naufal_mfz@yahoo.com

Affiliation: Business School IPB University, Jl. Raya Pajajaran, 16151, Bogor, Indonesia
} 
The total coverage of Labor social security programs in Indonesia based on the 2019 Program Report of the Labor Social Security Administration, or abbreviated as BPJamsostek, is 54,967,458 workers. This number is still relatively low compared to the number of Indonesians who work based on data from the Indonesian Central Statistics Agency in February 2020, which reported that approximately 131,030,000 Indonesians are currently employed. This is added to the dynamics of the loss of a number of current jobs and the emergence of a number of jobs in the future. Therefore, the role of labor social security practitioners is becoming increasingly important to achieve the target of fulfilling the coverage of Labor social security in Indonesia.

Labor social security practitioners referred to in this study are Account Representatives at BPJamsostek who are the spearhead in the search for Labor social security program membership. Based on the job descriptions contained in the BPJamsostek Board of Directors Regulation Number 22 of 2019, their main responsibility is acquiring new participants, getting back participants who leave, and retaining existing participants who are scattered throughout Indonesia. BPJamsostek is a public legal entity that organizes a Labor social security program based on Law Number 24 of 2011.

According to the results of a survey published by the World Economic Forum (WEF) in October 2020, by 2025 the repetitive work will be reduced from $15.4 \%$ to $9 \%$. New emerging professions will grow from $7.8 \%$ to $13.5 \%$. And by 2025 it is estimated that 85 million jobs will be replaced by machines, while there will be 97 million new jobs handled by humans, machines and algorithms.

\section{Literature Review}

\subsection{Labor social security}

In order to ensure access to health care and continuity of income, the International Labor Organization (2003) describes social security as the protection given by government to individuals and families, in particular in terms of retirement age, unemployment, sickness, injury, accidents at work, childbirth, or loss of income. In the meantime, according to the Constitution of the International Social Security Association (2016), social security is any scheme or program provided for by statute or other legislation that provides insurance, either in the form of money or products, in the case of accidents at work, occupational diseases, unemployment, childbirth, illness, disability, old age, retirement or death, and includes, among other things, benefits for children and other family members, health care, prevention, rehabilitation and long-term care benefits. This can include social insurance, social aid, mutual benefit programs, reserve funds and other regulations that are compliant with national legislation or practice and are part of the social security system of a country.

According to BPJamsostek (2017), Indonesia is developing social security programs focused on sponsored social security in the same way as other developing countries, for instance social security programs financed by participants and still dominated by staff in the formal sector and controlled by providers of social security.

\subsection{The fourth industrial revolution and the jobs of the future}

According to Merkel (2014), through the integration of digital technologies and the Internet with traditional industries, Industry 4.0 is a systematic transformation of all facets of development in the sector. Schlechtendahl, et. al. (2015) illustrates the concept of the speed factor of the availability of information, namely an industrial environment in which all entities are often related and able to exchange information with each other. Kagermann, et. al. (2013) conveys a more technological understanding that Industry 4.0 as an incorporation of Cyber Physical Systems (CPS) and the Internet of Things (IoT) and the Internet of Services (IoS) into industrial processes, including production and logistics and other processes. CPS is a 
technology in which the physical world and the virtual world are merged. By integrating physical processes and network computing in a near loop, this mixture can be realized (Lee, 2008).

However, the fourth industrial revolution is not just about smart and wired machines and systems (Schwab, 2017). The spectrum is much broader. What occurred concurrently, from gene sequencing to nanotechnology, and from green energies to quantum computing, was a surge of more breakthroughs in many aspects. The combination of these developments and their physical, interactive and biological interactions radically differentiates the fourth industrial revolution from previous revolutions. Changing the business model of each industry is another fact.

The fourth industrial revolution also gave rise to disruption (Kasali, 2017), and as a result of this disruption, many old jobs will fade even though they do not disappear at all, such as bank tellers. New jobs that did not exist 10 or 20 years ago, such as baristas, bloggers, web developers, software developers, smart chief listeners, smart kettle managers, big data analysts, cyber warriors, cyber psychology, cyber patrol, forensic cybercrime specialist, smart animator, game maker, smart control room operator, medical sonographer, prosthodontist, are currently emerging in the world.

Globally, Skinner (2018) notes that in the next decade, robots will replace nearly $40 \%$ of jobs in the United States, and 30\% of jobs in the United Kingdom, 35\% of jobs in Germany, and 21\% of jobs in Japan. The wider the financial services sector, the more vulnerable it is to automation. In particular, the banking industry will be affected. Citigroup estimates that 1 in 3 banking jobs will be lost by 2025 , while Deutche Bank estimates that half of banking jobs will be lost over the next decade.

Meanwhile in Indonesia, McKinsey and Company (2019) released their research that the world of Indonesian labor in the future is in a positive condition. Automation has the ability to increase productivity and growth in gross domestic product (GDP) and to create higher wages and business opportunities for Indonesian companies and Indonesian workers. In Indonesia, a total of 23 million workers could be replaced in 2030 by automation. However, on the other hand, between 27 million and 46 million new jobs could be generated in the same period.

\subsection{Competencies}

David C. McClelland, a Harvard University professor of psychology, wrote a paper in 1973 entitled 'Testing for Competence Rather than Intelligence', which caused shocks in the field of industrial psychology. Research by McClelland shows that while conventional academic aptitude and information content assessments are good academic performance predictors, they rarely predict exceptional performance in the workplace. McClelland later argued that the best predictor of outstanding workplace performance was a personal characteristic he called competence.

This paper significantly affected professional and public opinion and made the following 5 key findings:

school grades did not predict job success

(a) intelligence tests and aptitude tests did not predict job success or other important life outcomes

(b) tests and academic performance only predicts job performance due to its underlying social status relationship

(c) such tests are unfair to minorities

(d) competence will be better able to predict important behaviors than traditional tests.

In his book, 'The Competent Manager', Boyatzis (1982) describes competence as the fundamental characteristics of an individual resulting in productive and/or superior job performance. The use of the word competency has now become common. The underlying features include the motivations, attributes, abilities, aspects of self-image or social position of an individual, or a set of information. Boyatzis recognized that 
there are 19 general skills that excellent managers appear to have and grouped them into 5 classes of skills, namely: target and action management, leadership, management of human resources, managing subordinates and focusing on others.

In his book, 'Competence at Work', Spencer and Spencer (1993) describe competence as a fundamental characteristic of a person that is causally linked to the criteria referred to as the criteria for successful and/or superior performance in a job or situation, continuing Boyatziz's work above. Competency consists of 5 dimensions, namely:

(a) intelligence, referring to information and learning of a person, such as the knowledge of human anatomy by a surgeon

(b) skills, referring to the capacity of a person to perform certain tasks, such as the ability of the surgeon to perform surgery

(c) self-concept and values, refers to the attitudes, values and self-image of a person, namely the trust and self-image of a person

(d) characteristics, refers to physical characteristics and a clear response to situations or facts, good vision is a necessary characteristic for surgeons, self-control is also the ability to remain calm under stress

(e) motivations, feelings, desires, physiological needs or similar urges that drive action, for example, surgeons with a high interpersonal orientation take personal responsibility for.

In addition, Ganesh (2004) notes that competence is an underlying attribute of an individual that allows them to provide superior performance in a specific work, position or situation. These characteristics may include intelligence, talents, traits, social roles, self-image and motivations. The underlying function expresses itself in the form of actions, which helps to define abilities and quantify them.

\section{Research Methodology}

This research was conducted in the BPJamsostek working area, especially in major cities in Indonesia, namely: Medan, Pekanbaru, Palembang, DKI Jakarta, Bandung, Serang, Semarang, DI Yogyakarta, Surabaya, Balikpapan, Makassar, and Denpasar. The research was conducted in 2020. The research was conducted by taking an inventory and mapping the opinions of 335 labor social security practitioners related to the competence of labor social security practitioners.

The analytical tool used is descriptive statistics to obtain objective conditions for the competence of labor social security practitioners at BPJamsostek. The sampling method used for labor social security practitioners is purposive non-random sampling to the Account Representatives of BPJS Ketenagakerjaan Branch Offices throughout Indonesia. This method was chosen because Account Representatives are the spearhead in the search for Labor social security program membership. They have the main task of acquiring new memberships and fostering existing memberships that are scattered throughout Indonesia.

The research method used was a literature study, distributing online questionnaires to respondents, mapping respondents demographically, identifying the objective conditions of labor social security practitioner competence and discussion.

The results of the data processing describe the demographic conditions of respondents, the conditions for developing the competence of labor social security practitioners, perceptions of the importance of the competence of labor social security practitioners, the position of social security practitioners in institutions, and the readiness of labor social security practitioners to face the 4.0 industrial revolution and the emergence of jobs in the future. 


\section{Results}

\subsection{Demographic conditions of labor social security practitioners}

The research respondents were 335 labor social security practitioners who function as Account Representatives at BPJamsostek branch offices throughout Indonesia. The questionnaire was distributed online. The respondents consisted of 58.8\% male and $41.9 \%$ female. Most respondents were in the range of 26-30 years as much as $56.7 \%$ and the range of $31-35$ years $25.4 \%$. These 2 age groups dominate the Account Representatives at BPJamsostek. The rest are scattered across several age groups.

Based on work location, most of them are in the DKI Jakarta area, namely 37.3\%, while in other cities, namely Medan, Pekanbaru, Palembang, Serang, Bandung, Semarang, DI Yogyakarta, Surabaya, Balikpapan, Makassar, and Denpasar, are almost evenly distributed, ranging from 3\% to $9 \%$.

In line with the age range, the majority of respondents have worked as Account Representatives for less than 10 years, amounting to $91.3 \%, 25.4 \%$ for less than 3 years, $34.3 \%$ for between $3-5$ years amounting and $31.6 \%$ for between $5-10$ years.

Based on the education level, the respondents were dominated by bachelor's degree graduates (89.9\%), then master's degree graduates (8.4\%), and the remaining $1.7 \%$ were Associate Degree and Senior High School graduates. The educational background of the respondents was dominated by graduates in Management and Engineering, namely $24.2 \%$ and $13.1 \%$, respectively. The rest is in the range of $9 \%$ to $1 \%$ respectively from the fields of Law, Communication, Health, Nursing, Agriculture, and others.

\subsection{Competency conditions of labor social security practitioners}

Approximately $60.0 \%$ of the respondents know about the competency standards of labor social security practitioners, whilst the remaining $40.0 \%$ do not. However, although $40 \%$ do not know, $93.7 \%$ of respondents think that this competency standard is important or very important.

Regarding the importance of the process of developing the competency of labor social security practitioners, the majority of respondents stated that it was important at $48.0 \%$ and very important at $46.0 \%$. Meanwhile, $4.5 \%$ stated that it was quite important and the remaining $0.6 \%$ said it was not important.

For the level of urgency in the process of developing the competence of labor social security practitioners, the majority of respondents stated that they were urgent at $91.6 \%$ and the remaining $8.4 \%$ said they were not urgent.

Some respondents equally stated that the opportunity to obtain a competency development program for labor social security practitioners was evenly distributed, and some others stated that it was uneven, namely $47.5 \%$ and $52.5 \%$.

Most of the respondents' knowledge about the Industrial Revolution 4.0 was at the level of knowing, which was $86.0 \%$, with details, namely, knowing enough about $28.1 \%$, knowing $50.2 \%$, and knowing very well at $7.8 \%$. Meanwhile, those who were somewhat unaware were $6.0 \%, 7.5 \%$ not knowing, and $0.6 \%$ very ignorant.

The respondents' knowledge of job lost was also quite high, namely at $87.2 \%$, with details being sufficient to know $36.7 \%$, knowing $45.7 \%$, and being very knowledgeable of $4.8 \%$. Meanwhile, those who did not know were $7.8 \%, 4.5 \%$ did not know, and $0.6 \%$ did not really know.

The frequency of choosing the type of job lost based on the perception of labor social security practitioners was that the highest was ticket officers at $29.3 \%$, then cashiers $20.3 \%$, conventional drivers $19.7 \%$, bank tellers $17.5 \%$, customer service officers $7.9 \%$, and the remaining $5.3 \%$ consists of travel agency agents, factory workers, restaurant waiters, postmen, and others. 
The respondents' knowledge of emerging jobs or jobs in the future was even higher, namely $89.3 \%$, with details enough to know $37.6 \%$, knowing $47.5 \%$, and very knowing $4.2 \%$. Meanwhile, those who were somewhat unaware were $6.9 \%$, and $3.9 \%$ did not know.

The frequency of choosing types of work that will appear in the future based on the perception of labor social security practitioners is the digital marketer at $27.0 \%$, then web/apps/game developer at $23.4 \%$, big data analyst $20.8 \%$, drone operators $14.5 \%$, online drivers $12.1 \%$, and the remaining $2.2 \%$ consists of content creators, YouTubers, online couriers, and others.

Meanwhile, regarding the effect of the emergence of jobs in the future on membership in the Labor social security program, a number of $12.8 \%$ of respondents stated that it made participation reduced very significantly, $29.0 \%$ stated that it made it reduced but not significant, $6.0 \%$ said it had no effect, $28.7 \%$ stated making increase but not significant, and $23.6 \%$ stated making increase very significantly.

Regarding the readiness of respondents to face jobs in the future in the context of the acquisition of labor social security program membership, the majority stated that they were ready, namely $93.1 \%$, with details that stated somewhat ready $14.9 \%, 56.7 \%$ ready, and very ready $21.5 \%$. Meanwhile, those who stated that they were somewhat unprepared were $6.6 \%$ and $0.3 \%$ not ready.

\section{Discussion}

Labor social security practitioners are mostly assigned by BPJamsostek in the Jakarta area. This is because the main BPJamsostek branch offices are mostly located in Jakarta. Large companies register their workers for Labor social security programs at branch offices in Jakarta. Because Jakarta as the national capital is still the center of business in Indonesia, many lost and emerging jobs also occur in this region.

The very diverse educational backgrounds of labor social security practitioners, including from the fields of Management, Engineering, Law, Communication, Health, Nursing, and Agriculture, are very useful for them to acquire participants who also come from various professions both as formal and informal sector workers. This educational background is in line with the job requirements contained in the BPJamsostek Board of Directors Regulation Number 22 of 2019 concerning Job Descriptions for Regional Offices and Branch Offices, which states that the formal education requirements for labor social security practitioners as Account Representatives are Bachelor Degree accredited in all disciplines.

Opportunities for careers in institutions for labor social security practitioners are also wide open because based on the BPJamsostek organizational structure practitioners can achieve the highest careers as Deputy Director, Director, even as President Director. This is in line with practitioners' opinion; $34.9 \%$ stated that the highest position of labor social security practitioners in institutions is Deputy Director, then $29.9 \%$ is Director, and then $13.4 \%$ is President Director.

Competency is an underlying trait of an individual that helps them to provide superior results in a specific job, function or circumstance. This includes attributes such as knowledge, skills. traits, social roles, selfimage and motivation. The underlying characteristics manifest themselves in the form of behavior, which helps identify and measure competencies (Ganesh, 2004).

The results of this research indicate that it is necessary to immediately carry out a competency development process for labor social security practitioners considering that this competency development process is considered urgent and important and the opportunity to obtain this development program is not evenly distributed among practitioners. In addition, at this time certain types of work were lost as well as the emergence of certain types of work.

The number of existing jobs that will no longer exist exceeds the amount of new jobs that will be created in the future, even though job creation slows down while job destruction accelerates. Employers expect that by 2025 , current repetitive jobs will decline from $15.4 \%$ of employment to $9 \%$ and new jobs will grow from $7.8 \%$ to $13.5 \%$. Based on this, it is estimated that by 2025,85 million existing jobs will be replaced due to a 
shift from human labor to machines, while 97 million new jobs will emerge with a new division of labor between humans, machines and algorithms (World Economic Forum, 2020).

The majority of labor social security practitioners, amounting to $93.1 \%$, stated that they were ready to face future jobs in the context of the participation of the labor social security program. However, $41.8 \%$ of respondents said that the effect of the emergence of jobs in the future will reduce participation, although $52.7 \%$ of respondents stated that the emergence of jobs in the future will increase the participation of the Labor social security program.

Labor social security practitioners argue that the jobs that will emerge most are digital marketers, web/apps/game developers, big data analysts, drone operators, and online drivers. These jobs are all based on digital technology and are widely available in big cities. Readiness to face the emergence of jobs in the future needs to be supported by the competency readiness that practitioners must have.

\section{Conclusion}

The role of labor social security practitioners or the Account Representative as the spearhead of the search for Labor social security program membership is becoming increasingly important because the number of participants in the labor social security program is relatively low compared to the number of workers in Indonesia.

From the research results, it is found that the labor social security practitioners are bachelor's degree graduates who have various educational backgrounds. This is very useful for making acquisitions of potential participants who also have diverse work professional backgrounds from both formal and informal sector workers. Career opportunities up to the highest level within the institution for labor social security practitioners are also wide enough to become Deputy Director, Director, even as President Director.

It was also found that the majority of respondents (93.1\%) stated that they were ready to face future jobs in the context of participation in the labor social security program. However, this readiness must be supported by competency, because $94.0 \%$ of the respondents stated that the competency development process was important and $52.5 \%$ stated that the opportunity to obtain competency development programs was not evenly distributed among practitioners.

Because this research only involves labor social security practitioners, it is necessary to carry out further research involving other stakeholders, including the management of the Labor Social Security Administration, labor social security experts, the government, and educational and training institutions in order to obtain a more complete perspective on the framework of developing the competence of labor social security practitioners in Indonesia.

\section{References}

Andersen, J. G. (2012). Welfare states and welfare state theory.

Boyatzis, R. E. (1982). The competent manager: A model for effective performance. John Wiley \& Sons.

Djamin, A. (2016). Social Security in Indonesia Past, Present and Tomorrow (Social Security in Indonesia: Past Present, and Tomorrrow). Jakarta (ID): Indonesian Manpower Foundation.

Shermon, G. (2004). Competency based HRM: A strategic resource for competency mapping, assessment and development centres. Tata McGraw-Hill Education.

Hermann, M.; Pentek, T.; and Otto, B. (2015). Design Principles for Industrie 4.0 Scenarios: A Literature Review. Dortmunt (GE): Technische Universität Dortmund.

Husodo, S.Y.; (2009). Menuju Welfare State (Towards Welfare State). Jakarta (ID): Baris Baru.

Ikhwan, H.; dan Isbah, M.F. (2018). International Seminar: Expanding Social Security Coverage in The Disruptive Economy Era. Bogor (ID): Institut BPJS Ketenagakerjaan. 
Kagermann, H.; Lukas, W.D.; and Wahlster, W. (2013). Recommendations for Implementing the Strategic Initiative Industry 4.0: A Final Report. Frankfurt (DE): National Academy of Science and Engineering.

Kasali, R. (2017). Disruption. Jakarta (ID): PT Gramedia Pustaka Utama.

Lee, E. A. (2008, May). Cyber physical systems: Design challenges. In 2008 11th IEEE international symposium on object and component-oriented real-time distributed computing (ISORC) (pp. 363-369). IEEE. DOI: 10.1109/ISORC.2008.25

Li, A. T., Lin, Y. J., \& Lai, Y. P. (2011). The Building of the Competency Model for the Health Care Consultants: An Example Based on a Teaching Hospital in Central Taiwan. International Journal of Social Science and Humanity, 1(3), 199.

Lindbeck, A. (2006). The welfare state-Background, achievements, problems (No. 662). IFN working paper.

McClelland, D. C. (1973). Testing for competence rather than for" intelligence.". American psychologist, $28(1), 1$. https://doi.org/10.1037/h0034092

Merkel, A. (2014). Speech by Federal Chancellor Angela Merkel to the OECD Conference. https://www.bundesregierung.de/breg-en/chancellor/speech-by-federal-chancellor- angela-merkel-to-the-oecdconference-477432

Rys, V. (2011). Redefining Social Security: A Return to Fundamental Principles. Alphabet Library.

Schlechtendahl, J., Keinert, M., Kretschmer, F., Lechler, A., \& Verl, A. (2015). Making existing production systems Industry 4.0-ready. Production Engineering, 9(1), 143-148. https://doi.org/10.1007/s11740-014-0586-3

Schwab, K. (2017). The Fourth Industrial Revolution. New York: Currency.

Skinner, C. (2019). Digital Man: Revolution 4.0 Involves Everyone. Jakarta (ID): PT Elex Media Komputindo.

Spencer, L. M. (2003). Spencer. SM (1993). Competence at work. Modeles for.

Spicker, P. (2000). The Welfare State: A General Theory. California (US): Sage Publications.

Chouhan, V. S., \& Srivastava, S. (2014). Understanding competencies and competency modeling-A literature survey. IOSR Journal of Business and Management, 16(1), 14-22. 